\title{
The mindsets of political compromise
}

\section{Citation}

Gutmann, Amy, and Dennis Thompson. 2010. The mindsets of political compromise.

Perspectives on Politics 8, no. 4: 1125-1143. doi:10.1017/s1537592710003270.

\section{Published Version}

$10.1017 /$ s1537592710003270

\section{Permanent link}

http://nrs.harvard.edu/urn-3:HUL.InstRepos:31770316

\section{Terms of Use}

This article was downloaded from Harvard University's DASH repository, and is made available under the terms and conditions applicable to Open Access Policy Articles, as set forth at http:// nrs.harvard.edu/urn-3:HUL.InstRepos:dash.current.terms-of-use\#OAP

\section{Share Your Story}

The Harvard community has made this article openly available.

Please share how this access benefits you. Submit a story.

Accessibility 


\section{The Mindsets of Political Compromise}

Submitted and revised 7-31-10

Amy Gutmann

President and Christopher H. Browne Distinguished Professor of Political Science

University of Pennsylvania

president@upenn.edu

Dennis Thompson

Alfred North Whitehead Professor of Political Philosophy

Harvard University

dennis_thompson@harvard.edu

Acknowledgements:

We are grateful for research assistance provided by Erica Jaffe and Sigal Ben-Porath

\section{$\underline{\text { Abstract }}$}

Political compromise is difficult in American democracy even though no one doubts it is necessary. It is difficult for many reasons including the increased political polarization that has been widely criticized. We argue that the resistance to compromise cannot be fully appreciated without understanding its source in the democratic process itself especially as conducted in the U.S. The incursion of campaigning into governing in American democracy—the so called "permanent campaign"—encourages political attitudes and arguments that make compromise more difficult. These constitute what we call the uncompromising mindset, which is characterized by politicians' standing on principle and distrusting opponents. This mindset is conducive to campaigning but not to governing because it stands in the way of necessary change, and thereby biases the democratic process in favor of the status quo. The uncompromising mindset can be kept in check by an opposite cluster of attitudes and arguments-the compromising mindset-that inclines politicians to adapt principles and respect opponents. This mindset is more appropriate for governing because it enables politicians more readily to recognize and act on opportunities for desirable compromise. We explore the dynamics of these mindsets by examining the processes that the led to the compromises on tax reform in 1986 and health care reform in 2010. 


\section{The Mindsets of Political Compromise}

Why is compromise on major issues so hard in democratic politics when no one doubts that it is necessary? We argue that a significant source of the resistance to political compromise lies in the democratic process itself. The increasing incursion of campaigning into governing in American democracy—the "permanent campaign"1— encourages political attitudes and arguments that make compromise more difficult. The resistance to compromise is a problem for any democracy because it stands in the way of change that nearly everyone agrees is necessary, and thereby biases the political process in favor of the status quo.

The resistance to democratic compromise is anchored in what we call an uncompromising mindset, a cluster of attitudes and arguments that encourage standing on principle and distrusting opponents. ${ }^{2}$ This mindset is conducive to campaigning but not to governing. The resistance can and should be kept in check by an opposite cluster of attitudes and arguments - the compromising mindset-which favors adapting one's principles and respecting one's opponents. It is the mindset more appropriate for governing because it enables politicians more readily to recognize opportunities for desirable compromise. Political scientists have exposed the harmful consequences of misplaced campaigning, but have not connected this problem with the mindsets we analyze here and their implications for democratic compromise.

The influence of campaigning is not necessarily greater than other factors that make compromises more difficult, such as increased polarization and the immense influence of money in democratic politics. But the mindset associated with campaigning deserves greater attention than it has received, first, because it reinforces all the other factors. Even sharp ideological differences, for example, would present less of an obstacle to compromise in the absence of the continual pressures of campaigning. Second, unlike the other factors, campaigning is an essential and desirable part of the democratic process. It becomes a problem only when it interferes with governing-another equally essential part of the process. ${ }^{3}$ Finally, if we want to make democracy more friendly toward compromise we need to understand not only the partisan positions and political interests that affect compromise but also the arguments and attitudes that politicians use to resist or support it. 


\section{Two Compromises}

To begin to diagnose the resistance to compromises, we turn to two pieces of historic legislation-the Tax Reform Act of 1986 (TRA) ${ }^{4}$ and the Patient Protection and Affordable Care Act of 2010 (ACA). ${ }^{5}$

The TRA was the most comprehensive tax reform legislation in modern American history, achieved only after years of failed attempts. ${ }^{6}$ The historic effort began without much fanfare. In his state of the union address in 1984, President Reagan called merely for a study of the problem, with a report to be submitted after the election. The Congressional Democrats did not think he was serious about reform. Walter Mondale, his challenger in the election, showed no interest in making tax reform an issue, especially after making his comment that whoever was president would have to raise taxes.

The hard work on the bill began quietly, with experts meeting secretly in the Treasury Department. The proposals that came out of Treasury were turned into a bipartisan compromise, forged with the support of President Ronald Reagan, Democratic House Ways and Means Committee Chairman Dan Rostenkowski, and later with the help of Republican Chairman of the Senate Finance Committee Bob Packwood and Democrat Bill Bradley.

All supporters of the TRA gained something they desired, but all also made concessions that flew in the face of their most principled reasons for supporting comprehensive tax reform in the first place. Democrats wanted to end loopholes for special interests and the wealthy, but they also agreed to radically lower the top tax rate (from 50 percent to 28 percent). Republicans wanted to lower marginal tax rates, but they also agreed to eliminate $\$ 30$ billion annually in tax deductions, which resulted in the wealthy contributing a higher percentage of income-tax revenues than they previously had done.

Compromises-even the most successful ones, like the TRA - never satisfy pure principles. A major scholar of tax law, Charles Galvin, compares the TRA to a series of principled tax reform plans, and finds it lacking. He writes that "We are advised that this is the most sweeping legislation in fifty years, that it is a model of fairness and equity ... I dislike being a cynic or a spoilsport, but I am not at all convinced by the propaganda." 7 After it passed, its supporters rallied to its defense, calling it landmark legislation. It was-if compared to previous or subsequent tax reform. But judged by the very same set of moral principles invoked by its staunchest supporters, the TRA still fell far short. 
Now fast forward to the efforts to pass a health care reform bill in 2009-10.8 The issue played a major role in the campaigns leading up to both the Democratic primary and the general election. Most of the major candidates presented proposals that were more detailed than is usual in a campaign..$^{9}$ Once in office Obama made health care reform a priority. At first, he signaled that he was open to compromise on the details of his proposal, and then left the negotiations largely to Congressional leaders. (Relying on Congressional leaders was essentially the same strategy that President Reagan had followed with tax reform). When Congress was unable to reach agreement by the August recess, the campaign in effect began again, with opponents taking advantage of the break to mobilize opinion against the pending proposals - and often caricatures of the proposals. The effect was to end whatever small hope there might have been for bipartisan compromise. The reformers then turned to the task of compromise within the Democratic Party, a challenge that turned out to be nearly as great.

The first bill passed with only a five-vote majority in the House in November 2009. The Senate passed its own bill on the day before Christmas. As the leaders in the House and Senate were trying to forge a compromise between the two significantly different bills early in 2010, a special election in Massachusetts erased the Senate Democrat's filibuster-proof majority, and caused many moderate Democrats in both the Senate and the House to reconsider their support. The campaign mentality returned with a vengeance. Negotiations had to be postponed, the reform proposals divided, an unusual procedure (reconciliation) invoked, and the final result rendered less comprehensive than any of the original proposals.

Although the ACA was not bipartisan, it had the same characteristics that defined the TRA and all political compromises-mutual sacrifice and willful opposition. All those who voted for this bill gave up something that they thought valuable. Everyone who voted for one of the two bills agreed to disagree over the inclusion (or exclusion) of a public option, greater cost controls, the kind of mandated universal coverage, insurance coverage for abortion services, and abortion funding, among other issues. Both sides thought the compromises fell short of their principles because of the willful opposition on the other side. Although all who supported this compromise evidently believed the legislation would be better than the status quo, they also believed that the compromise bill could have been still better if only their opponents had been more reasonable. 
These two historic efforts vividly underscore how difficult it is to achieve compromise on comprehensive reform on major issues in U.S. political system. ${ }^{10}$ Although nearly everyone agreed that tax reform was long overdue and health care in dire need of change, political leaders struggled to reach the agreements, and the agreements fell short of what reformers had sought. Both addressed a major problem that had proved resistant to reform for many years, but only the TRA was widely considered to be a substantial improvement over the status quo. Many supporters of the ACA thought that it was only better than nothing

These episodes provide insight into the obstacles to compromise. They show how the defining characteristics of compromise-mutual sacrifice and willful opposition-map onto mindsets that favor or disfavor compromise.

To the extent that the tax and health care legislation were successful, both sides gave up something of value. The need for mutual sacrifice makes compromises inherently difficult. ${ }^{11}$ Citizens and their representatives have different interests and values, and naturally resist giving up something they care about, especially if they believe that one of their core principles is at stake. Supporters of the TRA and ACA believed that the compromises would improve the status quo, but the principled positions that reformers espoused - a simple and transparent tax code or universal and affordable health care coverage, for example-did not survive intact in the tangled process that produced the final legislation.

To the extent that these compromises were successful, the mutual distrust so easily generated by willful opposition was partially suspended. At least some of the parties respected their opponents enough to make the necessary concessions. But in both cases, the uncompromising mindset that distrusts opponents hung over the process and its aftermath. Supporters as well as opponents of both reforms continued to believe that the legislation could have been better if the other side had been more reasonable. Even in case of the TRA, the resistance was relentless, and the discontent rife. The opponents, under the influence of the uncompromising mindset, nearly prevailed. The supporters, only fitfully taking up the compromising mindset, nearly yielded.

Health care reform fared worse. Both the process and the result were more widely and severely criticized than any aspect of tax reform. The suspicion and distrust that are characteristic of the uncompromising mindset lingered even among Democrats. The progressive wing faulted their leaders and the President for betraying their campaign 
promises. Moderates complained that their colleagues did not appreciate how public opinion had shifted against the reform, and how vulnerable they were in the coming midterm election.

To be sure, political polarization is part of the story of why this compromise was so difficult. The lower degree of party polarization may well partly explain why bipartisan compromise was possible in the case of TRA but not the ACA. But it does not shed much light on why compromise on the ACA within the Democratic Party was at least as difficult as compromise on the TRA between the two parties. Nor is it sufficient to account for the widespread assumption that compromise on health care reform could have been more successful if Senators Orin Hatch and Ted Kennedy had been able to collaborate as they had many times in the past. ${ }^{12}$ Polarized profiles do not necessarily prevent political opponents from finding common ground. Even when the ideological profiles of political opponents are polarized, compromising mindsets can make a difference.

Political scientists disagree about the source of polarization in the U.S.-whether only elites have become more polarized, or also the electorate, and if the latter to what extent elites are the cause. ${ }^{13}$ Identifying more precisely the source of polarization could help in targeting reforms to reduce obstacles to compromise, but our analysis does not depend on resolving this disagreement. Whatever the source of polarization, understanding the mindsets we discuss here is also necessary. A compromising mindset can mitigate, while an uncompromising mindset can exacerbate, the effects of polarization on the dispositions toward political compromise of both political leaders and voters. The characteristics of these mindsets and their links to campaigning and governing apply to political leaders or voters or both.

To appreciate more fully how polarization affects compromise we need to consider its relation to the mindsets associated with campaigning and governing. Polarization clearly exacerbated the willful opposition that made both the TRA and the ACA so difficult. Unlike agreements constrained by impersonal forces, political compromises are the product of human wills, which each side believes could have been otherwise if their opponents had not been so obdurate. In democratic politics, moreover, the opposed wills are organized into parties and factions within parties. Resisting concessions in the negotiations in both the TRA and ACA were opposing parties and factions within parties that were suspicious of not only the opposition but their own leaders and colleagues. The most passionate supporters of each party and party faction also believed that their leaders could have gained more if 
only they had been bolder. These possibilities led to distrust of motives and doubts about the outcome. The distrust and doubt in turn reflected and reinforced the polarization.

Among the many differences between the processes that led to these compromises in the TRA and ACA, one is strikingly relevant to understanding the mindsets that prevailed. Tax reform was not an issue in the campaigns before or after the compromise, while health care reform was an issue before (and would continue to be afterward). Partly as a result, the process that led to the TRA was more responsive to the compromising mindset, and the process that produced the ACA more susceptible to the uncompromising mindset. The uncompromising mindset inherent in campaigns gained less traction and therefore had less influence in the legislative process later. Furthermore, the permanent campaign that reinforces that mindset has been more conspicuous in recent years than in the mid 1980s when the TRA was negotiated.

The spirit of the permanent campaign may be even more pervasive now than when the Clinton drive to reform health care failed. But the failure of that effort may have helped Obama: he could appeal not only to the lessons learned but also to the belief that his leadership offered the last chance to make any progress at all for several generations. Many also believed that if he failed on health care in his first year, he would not be able to govern effectively on the other issues for the rest of his term. Significantly for our argument, his success depended on his tilting more toward a governing mindset. Most of his political advisers warned that the unpopular comprehensive reform he favored posed significant electoral risks (for him and more immediately for Congressional Democrats). His persistence-especially after the Democrats lost their filibuster proof majority in the Senate-could plausibly be described as demonstrating a greater commitment to governing well than to campaigning successfully. ${ }^{14}$

To expose more clearly the sources of the resistance to democratic compromises exemplified in these two historic efforts, we first explain how the democratic process in the U.S. - its dual demands of campaigning and governing — depends on both kinds of mindsets. ${ }^{15}$ Then we show how the logic of the mindsets themselves makes compromise more or less difficult. Recognizing the distinctive logic of each is an essential step toward making more space for desirable compromises, and restoring a better balance between campaigning and governing in the democratic process. 


\section{The Constraints of Campaigning}

If public-spirited politicians want to make a positive difference by legislating change, why don't they anticipate the compromise problem in their campaigns and educate voters about the need for accommodation? Why do even politicians who claim to favor bipartisanship campaign with an uncompromising mindset? Surely they can foresee that this stance will stiffen the opposition and set up their supporters to resist compromise when it is time to govern.

Consider a politician running for President who declares that one of his priorities is to reform health care. Among other bold initiatives, he promises a "National Health Insurance Exchange to help increase competition by insurers" (which would include the so called public option). He states his unequivocal opposition to any law that requires everyone to buy health insurance (the individual mandate), an approach favored by his main rival in the primary. He promises that his health care reform "won't add a dime to the deficit and is paid for upfront." Although he presents himself as willing to "reach across the aisle" and look for common ground, he offers no concessions at all during the campaign. ${ }^{16}$

This portrait is a recognizable likeness of Barak Obama in the campaigns leading up to the election in 2008. But imagine a more compromise-inclined Obama. ${ }^{17}$ Instead of standing firmly in favor of a public option, this Obama decides to educate the public about the need for compromise. While expressing his own positions, he also states explicitly where he is willing to make concessions and outlines the deals he is prepared to accept. He announces that he is willing to compromise with the opponents of a public option by substituting optional state experiments. Suppose also that he anticipates one of the compromises that later was offered to try to resolve the abortion controversy: he would be willing to give states permission to bar the use of federal subsidies for insurance plans that cover abortion (and require all insurers in states that do not adopt this ban to divide their subsidy money into separate accounts so that only dollars form private premiums can be used to pay for abortions).

It is instructive to consider why no candidate is likely to campaign as this hypothetical Obama does. First, candidates are less effective in mobilizing and inspiring supporters if they talk more about prudent compromises than about their steadfast commitments. Their support and ultimately their success in the campaign depend on reaffirming their uncompromising commitment to core principles, and on distinguishing 
their positions sharply from those of their opponents. Voters need to see the differences between the candidates as clearly as possible.

Second, signaling a willingness to compromise on specific policies before your opponents offer anything in return is obviously not a strategy designed to achieve the most you can reasonably win in the legislative negotiations to come. This is not only a strategic imperative but also a moral requirement. Candidates have a responsibility to their followers to increase the chances of achieving what they promise. Furthermore, the process of compromise itself, properly conceived, involves mutual sacrifice, which expresses a kind of reciprocity that is absent when candidates make premature concessions.

Third, the terms of complex political compromises typically cannot be predicted in advance of negotiations. Indeed, they should not be: the most successful compromises like the TRA often engage the parties in modifying their own views about what is acceptable in the process of crafting the compromise. Even if Obama knew in general terms that he would need to compromise some of his campaign promises in ways that would not sit well with his base, he would have been unwise even privately to think he could anticipate the specific concessions that he would be willing to make in order to pass a health care reform bill. No one could have predicted the final shape of the health care reform bill, and few predicted some of the issues such as abortion that would become major sticking points.

A successful campaign strategy thus requires the opposite of a compromising mindset. It favors candidates who stand firmly on their principles, and condemn their opponents' positions at every turn. Candidates may have to modify their positions to reach independents, but that is as far as they can go, and even that gesture toward the center is often suspect in the eyes of their more ardent supporters.

But to govern, elected leaders who want to get anything done have to adopt a compromising mindset. Rather than standing tenaciously on principle, they have to make concessions. Rather than distrusting and trying to defeat their opponents at every turn, they have to respect their opponents enough to collaborate on legislation. In their acceptance speeches, many elected officials signal their intention to move to a compromising mindset by vowing to be everyone's president-or governor, senator, or representative-and declaring now to be the time for coming together.

The problem for compromise is that the campaign does not end the day after the election. In American democracy, it has become in effect permanent.18 This is one reason why so many citizens are rightly skeptical of "coming together" pronouncements. The 
expectations raised by the previous campaign continue to hang over the business of governing. Even when elected leaders recognize the desirability of compromise, their staunchest supporters still want to hold them to their campaign promises, and believe that their pleas for the need for concessions are exaggerated. At the same time, the preparations for the next campaign begin almost immediately. Positions remain rigid and differences further sharpen, as both sides look toward the next election. Individual egos play a role too. Politicians who want credit for passing legislation (or credit for stopping it) may refuse to cooperate with their allies (or try to undermine their opponents) when they don't get their way.

The more that campaigning comes to dominate governing in democratic politics, the harder compromise becomes. ${ }^{19}$ As the mindset useful for campaigning overtakes the mindset needed for governing, leaders - wherever they stand on the political spectrumare less likely to see, let alone seize, opportunities for desirable compromise. As Obama observed during an exchange with Congressional Republicans: "It's very hard to have the kind of bipartisan work that we're going to do because the whole question was structured as a talking point for running a campaign."20

Campaigning in an uncompromising style plays a moral as well as practical role in democratic politics. It is a necessary element of an electoral system with competitive elections, and therefore a legitimate part of the democratic process. But by making compromise more difficult, it obstructs governing, another no less legitimate and in many ways more central part of the process. That is the internal tension in political compromise: the democratic process requires politicians both to resist compromise and to embrace it. The uncompromising mindset that characterizes campaigning cannot and should not be eliminated from democratic politics, but when it comes to dominate governing, it obstructs the search for desirable compromises. It is like an invasive species that tends to spread beyond its natural habitat as it roams from the campaign to the government.

The problem is most pronounced in the U.S. where campaigns last longer and terms of many offices are shorter. But it is not entirely absent in any democracy in which the habits of the campaign persist in the routines of government. Several studies of the "Americanization" of campaigns have found that, although the character of campaigns varies according to local customs and political culture, nearly all are looking more and more like those in the U.S. ${ }^{21}$ As this trend continues, many other democracies are likely to confront the challenge of keeping campaigning in its place. 


\section{The Value of Compromise}

If the increasing domination of campaigning over governing is making compromise more difficult, why should we be concerned? After all, some compromises are undesirable, and politicians should sometimes stand resolutely on fundamental principles and oppose legislation that violate those principles.

The chief reason to be concerned is that the greater the resistance to compromise, the greater the bias in favor of the status quo. ${ }^{22}$ Little change can happen in democratic politics without some compromise, and almost no major change can happen without major compromises. Without compromise on health care and taxation or other major issues, the status quo prevails even if it preserves a policy that serves everyone's interests less well. Of course, the status quo can sometimes be defended against any of the available alternatives, but a general resistance to compromises implausibly presumes that the status quo is always more defensible than a compromise for change, or that it is always a mistake to yield something to one's political adversaries even when they are willing to yield something to you. Privileging the status quo in this way is not consistent with either a principled liberal or a principled conservative stance toward politics.

The resistance to compromise also undermines practices of mutual respect that are essential for a robust democratic process. The value of mutual respect is prominent in deliberative theories of democracy, where it supports the basic principle that laws must be justified by appealing to reasons that should be acceptable to free and equal persons seeking fair terms of cooperation. ${ }^{23}$ But mutual respect plays an important (though sometimes implicit) role in most other theories of democracy. It expresses the fundamental idea that citizens should be treated not merely as objects of legislation, but as autonomous agents who have the right to take part in the making of the laws. The process in which they exercise that right presupposes at least a minimal form of mutual respect, understood as a reciprocal positive regard shared by citizens that helps a democracy endure in the face of irresolvable moral disagreement. When parties enter into negotiations in bad faith, deliberately misrepresent their opponents' positions, and refuse to cooperate even on matters on which they could find common ground, they undermine relationships of respect that are necessary to sustain any morally justifiable democracy under the modern conditions of deep and persistent disagreement.

Finally, political compromises need to be encouraged because all compromises by their nature are perpetually vulnerable to criticism from all sides. Every compromise 
sacrifices something of value to each side, and gives rise to suspicions that but for the base motives of the other side the agreement could have been better. Although compromises are typically seen as (and often are) the products of unprincipled bargaining, and reinforcements of the prevailing balance of power, they are also sometimes the primary (and often the only) means by which democratic politics can improve upon the status quo. ${ }^{24}$

Compromise is of course not the preeminent value of the democratic process. Uncompromising politics has a large and valuable place not only in campaigns but also in social movements, protests, demonstrations, activist organizations and their surrogates in government. There would be nothing to compromise if there were no un-compromisers. As commentators noted, liberals need radicals, and presumably moderates need radicals on both sides. ${ }^{25}$ As political theorists and political scientists have long recognized, contestation is at least as important as consensus in a democracy. ${ }^{26}$ Contentious politics is not a necessary evil but an essential part of the democratic process. However, the value of compromise and the mindset that supports it are especially important in the legislative process for the reasons we have suggested, and therefore an especially important virtue that a critical mass of legislators and leaders should cultivate.

To make democracy safer for desirable compromise, we need to understand better how the uncompromising and compromising mindsets function-specifically, the strengths and weaknesses of the arguments they express and the attitudes they reflect. Examining each in turn can also show why the uncompromising mindset fits with campaigning, and the compromising mindset, with governing.

\section{The Uncompromising Mindset}

This uncompromising mindset has two dimensions: principled tenacity, which addresses the sacrifice that compromise entails, and mutual mistrust, which responds to the willful opposition that compromise involves. ${ }^{27}$

\section{PRINCIPLED TENACITY}

Because compromises often require both sides to sacrifice some of their strongly held principles to enter into the agreement, they may be resisted because they are thought to violate a deeply held core value. Taking a stand against compromise itself comes to be seen as the only principled position. "It is not the principled partisan, however obnoxious he may seem to his opponents, who degrades our public debate, but the preening, self styled 
statesman who elevates compromise to a first principle. For the true statesmen...are not defined by what they compromise but by what they do not."28 Standing on principle is of course sometimes an admirable stance to take in politics. Burke's speech to his constituents in Bristol-in which he defended following his conscience against the opinion of his electors-still has resonance. Profiles in courage still have the power to inspire our admiration. That is part of the source of the continuing influence of this mindset. ${ }^{29} \mathrm{But}$ if all politicians rejected all compromises that violate their principles, then no particular compromise would ever be acceptable.

How can one consistently accept the general value of compromise but reject particular compromises that violate one's principles? There are two common answers. The first tries to distinguish compromises of principle from compromises of interest, rejecting the former while accepting the latter. The second answer would accept some compromises of principle, but not those that would violate a basic human value of some kind. Neither answer is satisfactory.

\section{Principles v. Interests}

If we could distinguish disagreements about principles from those of interests, we could follow the common maxim: never compromise your principles, only your interests. The difficulty of compromising would diminish, and compromises would be more easily attained. The difficulty of compromising would diminish even further if we could transform most principles into interests. Indeed, this approach-distinguishing principles from interests, and trying to transform most principles into interests-is often recommended in the literature on dispute resolution. Try to turn disputes over principles into bargains about interests because (it is assumed) interests are amenable to bargaining while principles are not. The distinction is typically between material interests understood as income, wealth, and the things that money can buy, and moral principles interpreted as values to which individuals are committed as part of their identity or out of strong ethical conviction. When interests are at stake, it is thought to be easier to find a way for each side to give up something. When principles and related values are at issue, it often seems that one or both sides are giving up more than anyone should.

Many scholars as well as politicians have gravitated toward this position, perhaps because it rests on a distinction that seems high-minded-between material interests and principles of justice. ${ }^{30}$ The compromise-interests-not-principles maxim is frequently 
invoked as the way to resolve the moral ambiguity in political compromise. Michael Ignatieff, the leader of the Liberal Party in the Canadian Parliament and also a well known author of books on (among other topics) political ethics, succinctly articulates this position when he says: "Sometimes sacrificing my judgment to theirs is the essence of my job. Provided, of course, that I don't sacrifice my principles... Fixed principle matters. There are some goods that cannot be traded." 31

The maxim is attractive, and may well appeal to potential voters on the campaign trail. But neither its negative claim that principles cannot be compromised nor its positive claim that interests can be easily compromised is sustainable. The near absolute ban on compromise based on moral principle turns out to encompass almost all of democratic politics. The principles of fairness and equity that were prominently invoked in the drive for tax reform in 1986 certainly would have blocked any compromise on tax reform, despite the improvements on the status quo that the TRA achieved from the moral perspective of all its supporters. Everything at stake in crafting a compromise on health care could be assigned to either the category of a principle or an interest, but distinguishing the values in this way makes little sense. Presumably, universal health care coverage is a principle, so there can be no compromise that would cover less than the entire American population (or the entire citizenry if the principle is thought to apply only to citizens). Yet why wouldn't it be moral (and practical) to agree to cover more Americans than are presently covered, even if that entails compromising the morally defensible principle of universal health care coverage? Whatever our answer to this question, it cannot rest on the fact that universal coverage is a principle, not an interest. Presumably, the cost of health care to taxpayers is an interest, but why would it be moral to compromise on health care reform by agreeing to escalate the cost of health care beyond what a healthy economy can sustain or beyond what is needed to provide high quality health care and better outcomes? The main problem is not that the distinction between interests and principles is fuzzy (which it is), but rather that any distinction between interests that may be compromised and principles that should not will condemn too many potentially desirable compromises, most of which require some sacrifice of principle. Alternatively, if everything a politician wants to compromise is categorized as an interest, then the distinction justifies too many compromises of interests even when some citizens are unfairly disadvantaged or unduly burdened, or both.

The operative idea behind the positive claim that compromising interests is acceptable seems to be that a material interest-especially when it can be put in monetary 
terms - is easy to trade-off, since money is supposedly fungible while principles are presumably not. ${ }^{32} \mathrm{An}$ insurmountable problem with this claim is that few material interests, and almost no important material interests, present themselves in democratic politics unattached to moral principles. Containing the cost of health care is connected to, among other principles, the principle of providing all individuals with the basic needs of life. To many people, satisfying basic needs is a core moral principle. Most of the major material interests at issue in democratic politics - such as the fiscal health of social security, the extension of unemployment insurance, the provision of foreign aid-are similarly inseparable from fairness, equity, and other core principles of justice. Taxation is a clear example of a vast set of policies that obviously affect material interests, but one need only consider the claims made in debates about the estate ("death") tax, the progressive income tax, or taxes more generally to see that the policies significantly implicate fundamental values Both the proponents and opponents of these policies generally rest their case in significant part on principles of distributive justice.

\section{Acceptable v. Unacceptable Compromises of Principle}

Consider the best recent attempt to distinguish acceptable from unacceptable compromises. ${ }^{33}$ Avishai Margalit defends what he calls the "decent kind" of compromise. ${ }^{34}$ Most democratic compromises, he argues, are decent and should not be rejected on the basis of absolute principles. Proposed agreements should be compared to the status quo and subject to the morally messy processes of political negotiation. He would rule out few if any compromises that take place within the constraints of a constitutional democracy. He draws the line at compromises that "perpetuate cruelty and humiliation," which he calls "rotten" (as distinct from "decent"). ${ }^{35}$ Yet Margalit ends up advocating some violations of even his most basic principle. He supports compromises that permit cruelty and humiliation for an entire generation if the long-term benefits (in reducing cruelty and humiliation) are great enough. His absolute principle turns out not to be absolute after all. His attempt to draw a clear principled line founders for three reasons that will also frustrate the use of any such standard to determine in advance whether a compromise is acceptable.

The first reason is that any unconditional standard (at least any that is politically relevant) will block some decent compromises that improve on the status quo. This is why Margalit refuses to rule out all compromises that perpetuate humiliation and cruelty. For the very same reason, under some circumstances, rejecting compromises that perpetuate 
cruelty and humiliation for more than one generation may perpetuate even more cruelty and humiliation for even longer. The problem with driving a moral stake in the ground at one generation-or anywhere else-is that it arbitrarily limits the range of consequences that should be considered in assessing whether the compromise is an improvement over the status quo.

The second reason that any unconditional standard is not helpful is the flip side of the first reason. Standing on an absolute principle to reject a compromise should not imply that any other compromise (which does not violate the absolute principle) is acceptable. Surely we should want to criticize some compromises even if they satisfy the minimalist standard of not perpetuating cruelty and humiliation for more than a generation. ${ }^{36}$ Not even the rule "compromise whenever the policy is an improvement on the status quo" is unconditional. Some compromises that improve on the status quo are likely to block further progress and set dangerous procedural precedents-for example, by legitimating deception or manipulation by more powerful and privileged parties. Even qualifications to the status quo rule would be misleading were they to be elevated into unconditional principles. It may be morally preferable not to stand unconditionally on any pre-ordained principle-whether substantive or procedural.

The third reason why standing on unconditional principles (or any pre determined general principle) turns out to be untenable for political compromise is that no one can fully anticipate what the complex process of political compromise realistically can be expected to yield. Achieving the best possible outcome will depend in no small measure on the nature of the negotiations and the evolving political context. ${ }^{37}$ Before the fact, driving a principled stake in the ground and tenaciously refusing to move-if more than a negotiating tactic-is a prescription for thwarting progress that could be mutually beneficial. Even after the fact, judging compromises by a pre-ordained set of principles is not productive. Compromises are too easy to criticize simply because what everyone observes are the results-which are often morally incoherent-divorced from both the process and the alternatives that presented themselves at the time.

Compromises are usually a mélange of measures that reflect conflicting values, which no single theory or ideology could consistently encompass. The TRA included tax exemptions and loopholes that violated some of the very principles that the President along with leaders in the Senate and House invoked to defend the ultimate compromise. Every health care reform bill that had any chance of gaining a majority in Congress, let alone a 
filibuster-proof majority, not only failed to fully satisfy the core principles-universal coverage, affordability, and cost containment-but also included measures that expressed conflicting values-such as maintaining fee for service, exempting the most expensive employer health care benefits from payroll taxes (until 2018), and imposing cost controls on medical procedures. Thus to judge compromises as acceptable only if they are consistent with a principle or with some coherent set of principles is to put the compromise-but not the status quo-on the moral defensive. 38

The attempt to distinguish in a principled way between acceptable and unacceptable compromises backfires not because principles are themselves unhelpful in politics. Quite the contrary, principles are an invaluable guide to the directions in which politicians should want to head in a compromise, and their supporters should want them to head. Everything we say here about the limits of principled tenacity is consistent with the importance of politicians and citizens guiding their actions and assessments by principles. ${ }^{39}$ The problem for democratic compromise (and democratic politics generally) arises when principles are treated not as a set of directional signals but rather as a series of roadblocks to all those compromises that would move society only imperfectly and partially in only some of the right directions. ${ }^{40}$

\section{MUTUAL MistRUST}

The second dimension of the uncompromising mindset-mutual mistrust-focuses on the attitude of the agents. Politicians speak and act on the assumption that the opposition to what they advocate is motivated mainly by a desire to defeat them and their principles.

The most common form of this distrust is a cynicism about the motives of both the proponents and opponents of a compromise. As the cynicism about the motives of politicians spreads to cynicism about the process of compromising, particular compromises become easier to resist and condemn. When motives are in doubt, suspicions that a better compromise could have been achieved come to the fore. Compromising is a fertile breeding ground for these suspicions because the process involves the interaction of conflicting wills that, unlike impersonal forces, are susceptible to modification. This creates a persistent hope on both sides that more could have been achieved if only one or the other had held out for more. It spawns continual doubt about the motives of those who settled for less. At the 
extreme of mutual distrust, the complete defeat of the opposition comes to seem the only means to an acceptable conclusion. ${ }^{41}$

In the health care debate, politicians of both parties continued in the campaign mode as they sought a legislative agreement. Even in the earlier phases when a bipartisan compromise seemed not out of the question, both sides reinforced the mutual distrust by accusing each other of base motives. Health Care for America Now, a coalition of Democratic and labor groups, ran television commercials charging that Republican members of Congress (notably House Minority Leader John Boehner) were opposed to changing health care because "they are in the pocket of the insurance companies and already have good coverage for themselves." 42 For his part, Boehner was not above questioning the motives as much as the substance of the Democrats' bill: "For whom was this bill actually written? ... is it really for the radical special-interest and lobbying groups that invested millions to elect a cooperative president and Congress?"43 Although the mutual disrespect reflected in these recriminations was not the main source of the failure of bipartisan compromise, this kind of motive mongering is part of the uncompromising mindset that facilitates campaigning but certainly does not help create conditions where compromise is likely to be seriously considered.

The motive cynicism comes from partisan supporters of politicians as much as from their adversaries. Politicians make campaign promises on behalf of their party and their ardent supporters, but once elected they find that they cannot fulfill them and then have to compromise to get anything done. Their supporters accuse them of selling out, suspecting that the promises were made only to get elected. They are accused of wanting to hold on to office more than to keep their commitments to the platform on which they ran.

The paradigm is George H. W. Bush's reneging on his 1988 campaign promise: "Read my lips. No more taxes." 44 The promise vividly shows the uncompromising mindset at work. In the campaign it served a legitimate strategic purpose. It helped mobilize his base, and probably was a factor in his victory. His stand was clearly calculated to differentiate him from the Democratic opposition. Although politically convenient, the pledge to oppose tax increases was also consistent with his principles. There were no grounds for any specific cynicism about his motives beyond the general cynicism with which many often-and too easily-apply to the conduct of all politicians who seek election.

Once in office, Bush repeatedly tried to cut spending rather than raise taxes as a means to reduce the growing national deficit. But he could make no headway with a 
Congress controlled by Democrats in both the Senate and House. Rather than let the budget balloon even further, he agreed to a bipartisan compromise that raised several taxes as part of the 1990 budget agreement. His staunchest supporters felt betrayed more than did his partisan adversaries. His conservative challenger in the 1992 presidential primaries, Pat Buchanan, made effective use of Bush's promise breaking, portraying him as a hypocritical, purely self-seeking politician. Later, in the general election, Bill Clinton used Bush's reversal on taxes to support the accusation that he was untrustworthy. Motive cynicism began to loom larger than policy criticism.

It is not easy to avoid the cynicism that the uncompromising mindset creates. If politicians never make campaign promises, their commitments are suspect, and their campaign is likely to suffer. If they never break the promises, their compromises will be infrequent and their efforts to improve over the status quo are likely to falter. After Bush's "read-my-lips" promise, politicians have tried harder to avoid making such explicit pledges, but they still run on a general platform, and they still fall short of achieving their campaign goals. When they take office, and try to govern-with a compromising mindset-they are still vulnerable to the charge that they have abandoned the strong campaign commitments that were nourished by the uncompromising mindset.

But it is possible, even for the most politically minded politician, to tame motive cynicism. At one of the many moments at which tax reform nearly collapsed in 1968, House Speaker Thomas Tip O'Neill stood as the only member with the power to allow a second vote on bringing the bill to the floor for a vote. A group of Republicans had defied their President and voted against bringing it to the floor the first time. O'Neill believed their motives were purely political and for a while considered retaliating by acting on his own political inclinations. The Democrats had done their part, and "if the bill failed now, there would be no one to blame but the Republicans." 45 Had he carried out this plan, he would have become another exhibit in the pantheon of politicians who promote mutual distrust. Yet he finally rejected it, and decided to trust the President to help round up enough Republican votes to pass the bipartisan compromise. It is not that his motives were nobler than the Republicans. He may well have acted less out of regard for the public interest (or even partisan advantage) than respect for a personal aide and loyalty to Chairman Rostenkowski. The significant point is that setting aside distrust of the motives of opponents, which may be necessary to continuing a negotiation, does not require politicians themselves to be nobly motivated. 
To reach a compromise, then, politicians must adjust their wills as much as their reason. They must be able to turn a will to oppose into a will to cooperate. That involves a psychological shift as much as policy change. To avoid the spiral of distrust that motive cynicism generates, American democracy needs institutional changes that are designed to contain the ascendancy of campaigning. A recent defense of the ACA compromise against some progressive critics suggests that anyone who seeks more comprehensive reform should concentrate on changing the institutional facts of political life-including the filibuster, the accounting standards of the CBO, campaign finance and the "awesome power of money in politics" - that "make the enactment of [more desirable] sweeping legislation nightmarishly difficult." 46 To make these institutional changes, which themselves could count as comprehensive reform, would require precisely the kinds of broad-based compromises that tend to be blocked by the motive cynicism of the uncompromising mindset. A deeper appreciation of how destructive to democratic governance the dynamics of mutual distrust can be, and how that dynamic is fueled by motive cynicism, itself is a necessary first step toward making almost any major institutional reform practically conceivable in democratic politics.

The politicians who supported the TRC in 1968 were no purer or nobler of motive than those who opposed it, but enough partisans on both sides overcame the tendency to think only the worst of their opponents. The opposite happened in the case of health care. The cynicism increased as the negotiations went on. The compromise that finally emerged required a shift in attitude about motives, but even then only among some Congressional Democrats.

\section{The Compromising Mindset}

Like its opposite twin, the compromising mindset also tracks the two defining characteristics of compromise, but it turns them in a more constructive direction for governing. The compromising mind sees mutual sacrifice not as an occasion to tenaciously stand on principle or imprudently abandon principles merely to reach agreement but as an opportunity to adjust principles to improve on the status quo. We call this first dimension of the mindset principled prudence. The compromising mind also finds in willful opposition not excuses for distrust but resources for understanding among those who disagree. We call this mutual respect. Together these dimensions of the compromising mindset can increase the chances that the general value of compromise will play a role in judging particular 
compromises, and therefore the chances that desirable compromises will be recognized as such.

\section{PRINCIPLED PRUDENCE}

Principled prudence seeks to overcome the intransigence of standing on principle. It begins with a pragmatic recognition that compromise is usually necessary in a democracy to accomplish anything of significance. But it amounts to more than making a virtue out of the necessity of compromise. It has a moral component that stands as a reminder that the failure to compromise is to privilege the status quo. If a compromise really is an improvement, then the compromising mindset opens up opportunities for achieving greater justice.

Although (as we have suggested) it is a mistake to try to judge the overall value of a compromise by a set of coherent principles, it is still necessary to decide whether the compromise is an improvement over the status quo. That is the minimal condition for justifying any compromise. Such a justification requires showing that the compromise is an improvement from the perspective of all sides. Otherwise, the agreement is not a compromise, but a capitulation by one side to the other.

The judgment that a compromise is an improvement is in principle contestable, sometimes reasonably so. But in practice the objection that a particular compromise is worse than nothing is often disingenuous; it serves as a common tactic in the bargaining process. When the objection expresses a genuine comparison between the compromise and the status quo, it almost always assumes the possibility of achieving a better compromise in the foreseeable future. In that case, the objection is not that the proposed compromise itself is worse than the status quo but that it is worse than a hoped-for future compromise. This was the logic behind many of the Republican objections to the Democrats healthcare reform bills. "They are still trying to find a way to shove this down the throats of the American people," John Boehner commented after the Massachusetts Senate election that broke the Democrats supermajority: "Let's start over on common sense steps that we can take to make our system work better... No one in Washington thinks our current health care system is perfect and certainly not Republicans." 47

The problem with rejecting a compromise in the hope of a better one to come is that the rejection itself becomes an obstacle to reaching the future compromise. In this case, "starting over" was not a plausible prescription for achieving a bipartisan compromise 
because of the polarized politics of the Congress, and the uncompromising mindsets that prevailed. In all cases, the judgment about whether a particular compromise is worse than a hypothetical future compromise depends on an assessment of the political forces in play. Those assessments are almost always colored largely by the partisan views of the content of the compromises in question. The effect that rejecting a current compromise has on relationships among the parties, and their inclination to trust one another enough to engage in serious negotiations in the future, does not usually receive due consideration in the assessment. The compromising mindset cannot eliminate these biases, but it can help clarify the value of the current compromise by directing attention to the critical comparison: does the compromise promote the core principles of all parties better than the status quo?

Principled prudence also reverses the uncompromising perspective on the incoherence of compromises. It sees the incoherence of the principles underlying many compromises - the fact that the TRA combined concessions on tax loopholes and tax rates, and in the end was inconsistent with any single set of principles-as a sign of success. Such incoherence can be an indication that the democratic process respects opposing principles and values. If the process has been fair and the outcome an improvement, the disarray in the principles may be, if not celebrated, then at least appreciated.

Principled prudence should not be mistaken for being unprincipled. Some of the most successful compromisers are as well known for taking strong principled stands as they are for making difficult compromises. By the end of his time in Congress, Senator Kennedy had earned a worthy reputation for alternately standing on principle and adapting his principles when necessary to reform current policy in the direction that his core values would suggest. His role in health care reform is a case in point. When he decided to compromise, he had more credibility to defend the proposal to his allies. He had standing to say that this is the best we can get, and he provided cover for those in his party who might otherwise be accused of selling out.

Nor is principled prudence incompatible with partisanship-at least not with what has been called "respectable partisanship." 48 The most cogent defenses of partisanship impose on partisans rather strong ethical demands that support principled prudence. Partisans should advance principles but principles of justice they believe others could share; they should strive to "locate common ground," and should be "as ready to peacefully suffer [their] losses as to enjoy [their] victories." 49 In her astute defense of parties and partisanship, Nancy Rosenblum identifies the "disposition to compromise" as one of the 
three essential qualities that partisans must have if partisanship is to serve democratic politics well.50 When she first presents the idea, it seems that partisans need to display this disposition only toward their "fellow partisans." This is of course important. In the case of health care reform we have seen just why such a disposition is important within a party. But encouraging it within the party is not enough for a compromising mindset. Rosenblum herself later extends the duty to compromise beyond the party: partisans should seek cooperation "across the aisle."51 The "ethics of partisanship" rejects the "uncompromising extremism" that praises "intransigence as an avowed good" because it lacks a "commitment to getting the public business done." It represents an "abdication of responsibility for governing."

The partisanship that is worth defending is practiced by those who are prepared to make prudent but principled concessions. The compromising mindset permits parties to maintain their distinctive identities and to press their partisan agendas not only campaigning but also in governing. While they legitimately govern with an eye to the next election, they should also keep focused on making progress on their agenda even if when they happen to be in the minority. The aim is not to exclude partisan attitudes in governing but to maintain a better balance of mindsets than is evident in contemporary American politics.

\section{MUTUAL RESPECT}

The second dimension of the compromising mindset addresses the willful opposition that characterizes compromise. It counsels adversaries to negotiate in good faith and to restrain suspicions about ulterior motives: assume that your opponents' motives are mixed, that they act not only for their own political gain but also out of a desire to do what they think is right. In this way, without ignoring political realities, mutual respect counters the motive cynicism cultivated by the mutual mistrust in the uncompromising mindset.

Like toleration, mutual respect is a form of agreeing to disagree, but mutual respect brings with it more than the "live and let live" attitude of toleration. Mutual respect requires a favorable attitude toward, and constructive interaction with, the persons with whom one disagrees. It is the mindset of individuals who enter into negotiations in good faith, presuming their adversaries are as well motivated as they are, also trying to act (at least partly) on principle. 52 
Mutual respect is plainly a desirable ingredient in democratic politics, a virtue that makes debate more civil and relations more collegial. But it is more than that. In the case of compromise, it plays a special, more central role. To accept a compromise you (and your supporters) have to believe that you are getting as much as you can reasonably expect under the circumstances. You do not want to sacrifice your principles or disappoint your supporters if you could secure a better (more just) result by putting more pressure on your adversaries, or by holding out for more concessions. That would, as we saw, reinforce the motive cynicism that lurks in the hearts of politicians and voters.

The biggest challenge in defending an attitude of respect toward adversaries arises from the fact that the parties to a compromise cannot be certain that an agreement is the best they could achieve under the circumstances. This uncertainty infects not only ex ante but also ex post judgments about compromises. The answer to the question of what would have happened if one's side had resisted more strongly depends on a complex set of counter factual assumptions that are hard to assess objectively at any time. The uncertainty about the probabilities is far greater than the certainty about the principles, and the judgments therefore tend to be driven by more by the principles. (In this dynamic, principled tenacity is also reinforced.)

Under conditions of uncertainty, the trust that mutual respect generates is essential. It is one of the few resources on which the parties to a compromise can draw to assure themselves that they are getting as much as they can reasonably expect, and to assure their supporters that they are not selling out. If you and your supporters have reason to believe that your adversary is negotiating in good faith, you can have more confidence in deciding whether and how much to concede. If you and your supporters begin to suspect that your adversaries are engaged in duplicitous behavior, you are likely to resist a compromise even if it appears to be (and actually is) an improvement on the status quo. By the same token, compromise becomes more difficult to the extent that adversaries try to take advantage of the vulnerabilities of the other side, manipulate public opinion, or threaten political reprisals out of proportion to the issues at stake.

The cynical attitude that looks for ulterior motives in every move by political opponents is of course not entirely wrong. In politics, most people's motives are mixed . Accordingly, the process of compromise supplies more than enough evidence for motive cynicism. Early in the debate about health care reform in 2009, Senator Jim DeMint (South Carolina) urged his fellow Republicans to work against any reform so that the Democrats 
would suffer political losses. "If we're able to stop Obama on this, it will be his Waterloo. It will break him." 53 Even if few of his colleagues followed him, his call for all-out opposition served to strengthen the hands of the cynics who believed that the opposition was purely politically motivated. It also weakened the (already wavering) will of those with a more compromising mindset, who were hoping to craft a bipartisan compromise on health care reform.

Even worthy attempts to keep reaching out to opponents who persistently rebuff your approaches need not be driven mainly by noble motives. If opponents are unwilling to concede anything of importance, this approach may still offer valuable moral (and political) cover when they finally have to draw the line, and reject a putative compromise that would actually amount to a capitulation. Obama's chief of staff seemed to have something like this in mind when he claimed members of the administration could genuinely say that they tried for bipartisanship in health care reform, but they were not met half way. "The public wants bipartisanship... We just have to try. We don't have to succeed."54 The "try" was not entirely whole-hearted; the Democrats spurned at least one of the Republican's plausible offerscooperation on tort reform. Nor was it without political intent. "I don't think the onus is on us. We tried. The story is they [the Republicans] failed." 55 Nevertheless, by taking the high ground and reaching out to opponents, politicians make a symbolic statement and keep open the possibility of cooperation on the basis mutual respect. Whatever their intentions, they may find that their opponents may even take them up on their offer. If it turns out that their opponents still show no willingness to compromise, they not only gain some high ground but also demonstrate that they are not the ones blocking cooperation across partisan or factional lines.

The window of compromise rarely opens to politicians who always assume the worst of the motives of their adversaries. It typically takes repeated outreach to adversaries, accompanied by at least a temporary suspension of motive cynicism, to discover opportunities for compromise, especially the comprehensive kind like the TRA. President Reagan reached out to Democrats as well as to Republicans to pull off the compromise that became the TRA. So did Rostenkowski, who worked closely with receptive members of both parties on his Ways and Means Committee. Political motives were at work in both cases, but the leaders did not dwell on them.

A striking illustration can be found in the role played by Bob Packwood and those who reacted to his shifts on this issue. When he changed from opposing to supporting tax 
reform in 1986, he must have calculated that opposition to a successful tax reform bill would jeopardize his chances for re-election at a time when his party's popular President had made tax reform a chief domestic initiative for the second term of his presidency. It would have been easy-and not inaccurate-for both supporters and critics of the compromise to suspect Packwood's motives. He could have been portrayed as interested only in re-election, and as hypocritical for abandoning his long-standing position on the issue. "On taxes, I'm as predictable as the sun rising." In his own words he had always been "a big [tax] credit man." 56 Belying the prediction of his own predictability, Packwood decided to partner with Democratic Senator Bradley to pass the tax reform in the Senate, a bill based on the House version, which many House Republicans had declined to support. According to Bradley's admiring account, Packwood "became a fearsome and effective supporter of tax reform." 57 The bipartisan support for tax reform probably would have broken down had motive cynicism rather than mutual respect dominated the tax reform process. ${ }^{58}$

The kind of broad-based mutual respect that emerged in the negotiations over the TRA is more easily cultivated in governing than in campaigning. In governing, it can produce legislative results (if all goes well). In campaigning, it is not as useful as motive cynicism in producing electoral results (if all goes as usual). A campaign is a competitive, zero-sum activity. Defeating your adversary is the dominant and legitimate motive. The more these campaign attitudes infiltrate the legislative process, the less the scope there is for mutual respect.

Because campaigning fuels motive cynicism, it needs to be contained for the sake of democratic governance. Governing must be given a chance to cultivate mutual respect. When given a chance, the governing process has some defenses against the tendency of campaigning to incite motive cynicism.

One defense is "economizing on moral disagreement."59 This practice encompasses several different strategies. As the first step, it would encourage politicians to find common ground by dividing issues into more and less contentious parts, and to conclude deals on those on which there is agreement, as a way to build mutual trust for agreements over time. But this strategy is of limited use in the case of comprehensive changes such as those involved in health care reform. The parts of the reform are too closely interconnected. Everyone may agree that costs should be contained but many still resist the mandates 
required to achieve the universal coverage necessary to control increases in insurance premiums.

A more promising general strategy is to seek cooperation on other issues on which there is more hope for agreement. Even those who disagree about abortion may still agree, for example, on the importance of providing pregnant teenage girls the support they may want and need to become mothers. The abortion compromise in the heath care debate was much more limited, consisting mainly of an agreement not to adopt anything that would change the current law. Even as the parties continued their contentious debate about health care in early 2010, Congress managed briefly to pass a modestly bipartisan bill intended to create jobs, a goal that everyone shared. The flame of mutual respect did not shine brightly for long, but it was a signal pointing in the right direction.

The governing process is more likely to encourage mutual respect through this other-issue type of cooperation to the extent that it takes place in institutions that require politicians to work together on a continuing basis, and permits them to cultivate reputations and relationships across oppositional divides. Trust is more likely to be generated not in one-time negotiations but over time as politicians who oppose one another on some issues find ways to work together on others. As mutual mistrust once in play creates a spiral of suspicion that is hard to stop, so mutual trust once established is selfreinforcing. ${ }^{60}$ It can persist even in face of strong disagreements and ideological polarization. In the presence of mutual trust (along with principled prudence), the strong ideological differences that characterize a polarized politics need not stand in the way of cooperation and compromise. The collaborations of Orin Hatch and Ted Kennedy (mentioned earlier) are exemplary in this respect. Despite being part of the right and left wings of their parties, respectively, they managed "to come together in a bipartisan fashion to craft some of this nation's most important health legislation."61 During almost two decades they alternated as Chairman and Ranking Member of the Senate committee concerned with health care, education and labor issues, they co-sponsored legislation that, among other results, provided support for victims of AIDS, created the children's health insurance program, and established protections against discrimination toward individuals with disabilities.

The third important strategy of economizing on disagreement takes for granted that the disagreement will persist across on most issues. The democratic process does not always or even usually yield agreement, let alone general consensus. Dealing with the 
disagreement that is endemic in democratic politics in a respectful way is essential to reaching desirable compromises, whether now or in the future. Even rhetoric can make a difference. How politicians describe not only the substance of their opponents' proposals, but also their motives affects the possibility of mutual respect.

Economizing requires a particular kind of verbal self-restraint in politics: it counsels avoidance of extreme exaggeration of the positions of opponents. Some Republican opponents of the Democratic proposal to fund end-of-life counseling fastened on the label "death panels," suggesting that the Democrats' proposal would force euthanasia on the infirm elderly. 62 They may have succeeded in temporarily obstructing the healthcare reform process, but they also demonstrated such disrespect for their opponents that they sacrificed the respect of some potential allies who were not among their core party loyalists. The ViceChair of the Senate Republican Conference set a better tone: "It does us no good to incite fear in people by saying that there's these end-of-life provisions, these death panels...Quite honestly, I'm so offended at that terminology because it absolutely isn't (in the bill). There is no reason to gin up fear in the American public by saying things that are not included in the bill." 63

\section{$\underline{\text { Conclusion }}$}

To campaign successfully, politicians must mobilize and inspire their supporters. They have to articulate a coherent vision distinct from that of their opponents, and present their opponents as adversaries to be distrusted and ultimately defeated. But to govern effectively, politicians must find ways to reach agreements with their opponents, including members of their own ideologically diverse parties, even compromises that their own supporters may see as betrayals. This tension between what is required in a democracy to win power and what is required to exercise it is manifest in what we have called mindsets. These clusters of attitudes and arguments arise from the distinct pressures of democratic campaigning versus governing, and they frame the way politicians and the public view opportunities for, and the results of, compromises. The uncompromising mindset-marked by principled tenacity and mutual mistrust-is well suited for campaigning. The compromising mindsetcharacterized by principled prudence and mutual respect-is more appropriate for governing. It is not that one is legitimate and the other not. Each has its place in the democratic process. But to the extent that the uncompromising dominates the compromising mindset in the process of governing, compromises that could reduce 
injustice or increase well being go unrecognized and unsupported. When the uncompromising mindset overwhelms political thinking and action, it biases the democratic process in favor of the status quo.

It would be a mistake to try to specify exactly when a leader should adopt which mindset. That would be like the attempt to specify precise principles in advance for distinguishing between acceptable and unacceptable compromises, which we have shown is bound to be under-inclusive or over-inclusive, if not both. Nevertheless, it is clear enough that the democratic deck is stacked against compromise in contemporary American politics (and increasingly in democratic politics more generally). The uncompromising mindset is ascendant, straying well beyond its natural habitat. To tame it, politicians and citizens need to better understand it and its compromising twin.

Understanding more clearly these different ways of framing disagreement can help overcome the obstacles to agreement and lead to more beneficial compromises. Political polarization is of course also an obstacle, but as we have suggested it is only part of the problem, and in any case the ways in which it affects compromise can be adequately appreciated only by probing the mindsets we have analyzed here. Political moderates with an uncompromising mindset are prone to block compromise just as conservatives and liberals with a compromising mindset join together when necessary to support compromise, as did Ronald Reagan and Tip O'Neill to pass the TRA. Senators Hatch and Kennedy were not ideological moderates, but they adopted the compromising mindset in order to craft important democratic compromises.

Even politicians with the appropriate mindsets need institutional support to succeed in democratic politics. Institutional reforms are therefore an important complement to recognizing the difficulty created by the dominance of campaigning over governing for democratic compromise.64 Yet major institutional change that would make a significant difference itself requires compromise, and the leaders who would bring it about will themselves have to set their minds to it.

Political leaders and ordinary citizens alike could benefit from seeing more clearly the strengths and weaknesses of the compromising and uncompromising mindsets, and how they interact in the democratic process. The ways that the mindsets frame disagreements are sometimes latent and often unrecognized. By more fully appreciating the very different mindsets required by campaigning and by governing, leaders and citizens are 
more likely to recognize opportunities to make compromises that could make better laws for all. 


\section{NOTES}

1. Jones 1998; Ornstein and Mann 2000; and Heclo 2000.

2. We use "mindsets" to refer to both cognitive and dispositional states, which include how people tend to conceptualize and argue about issues as well as how they are inclined to act on the conceptualizations. Mindsets manifest a form of what psychologists call cognitive bias, but we do not assume that the bias in the mindsets we discuss necessarily leads to mistaken conclusions or actions. In political science, the concept that comes closest to our use of mindset is "framing," which has been defined as "the process by which people develop a particular conceptualization of an issue or reorient their thinking about an issue" (Chong and Druckman 2007; and Druckman 2010). We focus on the mindsets of political leaders more than on those of citizens. Political philosophers generally have not studied the content of mindsets because it lacks the rigor and scope of a theory. But, as we show here, mindsets have a cognitive structure: they presuppose moral values, express arguments, and imply theoretical commitments. Critical analysis of their structures could benefit from more normative attention from political philosophers as well as from more empirical investigation by political scientists.

3. It is sometimes suggested that the question of whether the "campaign style of governing" is a "positive development for democracy" turns on whether one adopts a trustee or delegate theory of representation. "The trustee preserves the distinction between campaigning and governing; delegates are much less the purists, seeking throughout their service to mirror the interests and concerns of their constituents" (Jones 2000, 196-97). But the distinction cannot be so sharp. On any democratic trustee theory, leaders must take into account the effect of their decisions on the next election; and on any plausible delegate theory, leaders must have sufficient time before being held accountable to try to carry out the policies their constituents favor. .

4. A summary prepared by the staff of the Joint Committee on Taxation (July 14,1986) is available at: http://www.archive.org/details/summaryofhr3838t1486unit 
5. The health reform legislation consists of two acts: the ACA, the Senate version passed by the House and signed into law on March 23 2010, and the Health Care and Education Reconciliation Act, intended to meet objections of House members and signed into law on March 30. The latter consists entirely of revisions and is unintelligible standing alone. A consolidated document incorporating the revisions into the ACA was prepared by the House Office of Legislative Counsel and appears to be the only full text of the reform, though it does not have the status of law: Ppaca\&Hcera;PublicLaws 111-148 \&111-152: ConsolidatedPrint available at http://www.ncsl.org/documents/health/ppacaconsolidated.pdf

6. Our account relies on Birnbaum and Murray 1988; Strahan 1989; Conlan et al. 1989; and Witte 1991.

7. Witte 1991, 440.

8. Our account relies on the Staff of the Washington Post 2010; Alter 2010, 244-66, 395421; and Hacker 2010.

9. Obama came late into this process, developing his health care plan after other candidates had presented theirs, as described in Staff of the Washington Post, ch. 1.

10. We are not trying to provide a causal explanation for why these compromises happened or why one was more successful than the other. Neither the mindsets nor the permanent campaign are necessary and sufficient conditions for the failure or success of compromise in these cases or more generally. As the best analyses of these compromises show, the causes are multiple and probably over-determined: Birnbaum and Murray; Conlan et al. 1989; Alter 2010; and Hacker 2010. However, we are suggesting that an appreciation of the role of the mindsets is important for understanding the dynamics of the negotiations, the interactions of the politicians in these cases, and the process of compromise in general.

11. Henry Richardson distinguishes two forms that this mutual sacrifice can take: "bare compromise," which involves a "willingness to accept a less satisfactory means to the ends 
one started with," and "deep compromise," which requires a "reconsideration of what is worthy seeking for its own sake...a change in one's ends" (Richardson 2002, 146-47, 14461). He devotes most of his attention to deep compromise, which (we agree) is a worthy ideal in democratic politics, and the pursuit of which can support the mutual respect in the compromising mindset we describe below. But in our view the value of the "willingness" in the more common bare compromise is no less important.

12. Alter 2010, 249.

13. McCarty et al. 2008; Fiorina and Abrams 2008; Fiorina et al. 2011; and Brownstein 2007.

14. Hacker asks why Obama used his "muscle to shape the bill in ways that made it demonstrably less popular with Americans..." and suggests that the "briefest answer" is that he wanted to get good 'scores' from the CBO [Congressional Budget Office]. It could be said (consistent with this answer) that while the CBO approval was politically important, his priority was also good government (Hacker 2010, 23-24). \{check pages\}

15. Some theorists have emphasized that the democratic process requires and reinforces compromise, and some have also found constraints on compromise in the process itself. See Kuflik 1979, 41-44, 38-65; and Dobel 1990, 79-99. Others have argued that negative attitudes toward compromise are "rooted in the nature of political life" (as in the problem of dirty hands): Carens 1979, 139, 123-41. But none has suggested that the process itself can create obstacles to compromise by means of the tension we analyze between the mindsets of governing and campaigning.

16. The quotes and comments are adapted from Obama's statements and speeches during the campaign: Organizing for America 2008-2002. On the dispute with Hillary Clinton about the individual mandate see: Factcheck.org 2007.

17. In private Obama is reported to have indicated that once in office he would be inclined to compromise on health care. Alluding to the Clintons' failed effort, he said he would not 
develop his own plan, drop it on the Capitol steps like a stone tablet, and refuse to bargain. "If Daniel Patrick Moynihan or Bill Bradley or John Chaffee came to me with the possibility of compromising, I'm not going to tell them, 'It's may way or the highway'” (Alter 2010, 249).

18. For the factors that support the trend toward the "permanent campaign," see Heclo 2000.

19. The permanent campaign damages the democratic process in other ways as well (for example, the preoccupation with fundraising and the excessive influence of contributors), but they have received more attention than its effect on compromise: see Ornstein and Mann 2000, 224-30.

20. Baker and Hulse 2010.

21. Plasser 2002, 15-106, 343-52; and Blumer and Gurvetch 2001, 380-403.

22. Brady and Fiorina $(2000,154-55)$ suggest that the "permanent campaign" is not a problem when voters do not want Congress to act (as during the period of large budget surpluses in the late 1990s) but it becomes a serious hindrance when voters "believe the government should take some action to alleviate a problem" (as presumably in the case of health care reform).

23. Gutmann and Thompson 2004, 3-7, 79-94,133-35, 151-56; Gutmann and Thompson 1996, 79-91.

24. This justification for compromise is pragmatic in the broad sense stipulated by Simon Căbulea May, who criticizes advocates of "moral" compromise (including us) for failing to recognize that "moral compromise in political life is only ever warranted for pragmatic reasons" (May 2005, 317). In pragmatic compromise "moral disagreement gives rise to a reason for compromise, not in itself, but only insofar as it is contingently connected with a logically independent consideration" (320). Moral compromise "involves an intrinsic appeal 
to disagreement: reasonable moral disagreement gives rise to a reason for compromise in itself, aside from any impediment to other goals it may incidentally generate" (320). Drawn in this way, the distinction is not helpful in analyzing political compromises, nearly all of which involve an appeal to independent moral values such as justice or welfare. Moreover, pragmatic reasons to compromise, as May acknowledges, are not sufficient and typically must be morally constrained in various ways (322-23). In our view, the value of mutual respect in democracy provides some of those moral constraints, none of which is a sufficient reason to compromise, but all of which facilitate the compromising mindset.

\section{Kuttner 2000.}

26. See for example Tilly and Tarrow 2006. The classic theoretical statement of the value of contention is of course John Stuart Mill's On Liberty (Mill 1977). Some recent democratic theorists have presented a more radical appreciation of contentious politics, or in their terms, of the need "to come to terms with 'the political' in its antagonistic dimension (Mouffe 2009, 129).

27. Our approach thus treats compromise as both a process and outcome. For an analysis of the concept that brings out this dual nature of compromise and its foundation in mutual respect, see Kuflick 1979, 38-65.

\section{DeLay 2006.}

29. Deliberative democratic theory is sometimes associated with this practice of taking principled stands, and indeed it does emphasize the value of principled arguments in politics, but most deliberative theorists not only recognize but also insist on the need for and value of political compromise. See Mansbridge et al. 2010.

30. For a discussion that presents a distinction between compromises of principles and interests (concluding that some of the former are acceptable), see Benditt 1979, 26-37. 
31. Ignatieff 2007. But he adds: "Knowing the difference between a good and a bad compromise is more important in politics than holding onto pure principle at any price. A good compromise restores the peace and enables both parties to go about their business with some element of their vital interest satisfied."

32. Another reason that compromises of interest seem more acceptable is that they lend themselves to the familiar technique of splitting the difference. See Benjamin 1990. However, there is no guarantee that any equal or mid-point division of interests is the fairest available compromise. Whether it is depends not only the content of the compromise, but also on the background conditions, including the relationships among the parties (for example, those that manifest mutual respect). Despite the title of his book, Benjamin's criteria for an "integrity-preserving compromise" refer to the attitude of the parties toward the compromise (their commitment to mutual tolerance) and the reasonableness of the positions in dispute (the uncertainty due to moral complexity) (3245).

33. Margalit 2009.

34. Margalit 2009, 39.

35. Margalit 2009, 2.

36. Margalit's criteria for "sanguine compromises" (for example, "recognizing the point of view of the other") may be intended to provide a way of distinguishing better and worse decent compromises (41-54). But the criteria refer to the process more than to the content of the compromise, and in any case they are not unconditional as is his cruelty and humiliation standard.

37. As the emphasis in the research on negotiation has shifted in recent years toward more descriptive approaches, the studies have shown that outcomes cannot usually be predicted by formal criteria such as Pareto-optimality, and are determined by a much wider range of variables than had been earlier assumed. See Thompson et al 2010. 
38. Ronald Dworkin's ideal of integrity—“lawmakers [should] try to make the total set of laws morally coherent" —-would if applied strictly also rule out many desirable compromises (Dworkin 1986, 176). "A compromise must be external, not internal; it must be a compromise about which scheme of justice to adopt rather than a compromised scheme of justice" (179). To the extent that the ideal is so applied, it reinforces the uncompromising mindset. But Dworkin does not carry the ideal this far. The "internal compromises" to which he specifically objects are what he calls "checkerboard compromises," in which a single principle is affirmed for one group but denied for another, as in a law that would make abortion criminal for pregnant women born in even years and lawful for those born in uneven years $(178,436 \mathrm{n} 7)$. In contrast, a compromise that orders or combines two different principles, such as a law prohibiting abortion except in the case of rape, does not violate the integrity ideal, even though it may be inconsistent from both the pro life and pro choice perspectives. For a more nuanced criticism of "internal" compromises, see Besson 2005, 257-84.

39. It is also possible and for some purposes desirable to develop a set of considerations that leaders should take into account when deciding whether to accept a compromise. John Stuart Mill in effect developed such a set when faced with the challenge of applying his own principles while serving in Parliament. His criteria (with one exception) were not intended to identify unacceptable compromises, but rather to specify factors that made compromises more or less objectionable. See Thompson 2007, 166-99.

40. One of the defining features of deliberative democracy in our view-the provisionality of principles - supports this limit to principled tenacity. The process of mutual reasongiving in deliberative democracy requires that citizens and leaders treat their principles as open to change. They are expected to take seriously new evidence and arguments, and new interpretations of old evidence and arguments, including reasons offered by their opponents and reasons they may have rejected in the past. Gutmann and Thompson 2004, 6-7, 57-59, 110-19. This openness to change over time, the basis for the self-correcting capacity of deliberative democracy, can also help constrain the uncompromising mindset and promote desirable compromise. 
41. In light of the fact that not a single Republican voted for the final health care bill, Hacker writes that "had moderate Republicans joined with Democrats, the bill would have been much closer to the ideal points of GOP legislators. But that only makes it all the more notable that Republicans held together, taking the risk of a bill with a stronger Democratic stance in return for gambling for the outcome they almost realized: complete and total victory" (Hacker 2010, 28, italics added).

42. Seelye 2009. (Seelye called the ads "misleading.")

43. Boehner 2009.

44. Bush 1988.

45. Birnbaum and Murray, 166, 160-173.

46. Jonathan Cohn, “How They Did It: The Inside Account of Health Care Reform's Triumph, The New Republic, June 10, 2010, 25.

47. Murray 2010.

48. Muirhead 2009; and Muirhead 2006..

49. Muirhead 2009, 392.

50. Rosenblum 2008, 361-62.

51. Rosenblum 2008, 401-08. Also see the recent symposium devoted to this book in this journal "Parties, Partisanship, and Democratic Politics" 2009.

52. Ideally, mutual respect includes the possibility of changing one's mind about the means or ends of a proposed policy, and even about the framework for negotiation: see Bohman 1996, 91-92, 89-104; and Richardson 2002, 146-47, 144-61. Staying attentive to this 
possibility is in our view a desirable component of the compromising mindset, though not a necessary condition for justifying a compromise, or for adopting a compromising mindset

53. Smith 2009.

54. Lizza 2009, 24.

55. Ibid.

56. Birnbaum and Murray, Showdown at Gucci Gulch, 19, quoted in Witte, 450.

57. Bradley 2009.

58. For more on how what we call the suspension of motive cynicism may have worked, see Strahan, 381; and Witte, 447, 450.

59. Gutmann and Thompson 1996, 84-94; Gutmann and Thompson 2004, 7, 85-90, 92, 18187.

60. According to a recent survey of the literature on negotiation, "mutual trust is an essential ingredient in effective ...negotiations." (Thompson et al 2010).

61. Statement by Senator Orin Hatch on the Passing of Senator Ted Kennedy August 26, 2009, http://hatch.senate.gov/.

62. Nyhan 2010; Alter 2010, 257. On the other side, some liberal Democrats - "imitating tea-party conservatives" - turned on their own kind and proposed running TV ads "against foot-dragging moderates they considered DINOs ('Democrats in name only') (Alter 2010, 407).

63. Demer 2009.

64. For examples of these reforms, see Ornstein and Mann 2000. 


\section{REFERENCES}

Abramowitz, Alan I. 2010. The Disappearing Center: Engaged Citizens, Polarization and American Democracy, New Haven CT: Yale University Press.

Alter, Jonathan. 2010. The Promise: President Obama, Year One, New York: Simon \& Shuster.

Baker Peter, and Carl Hulse. 2010. "Off Script, Obama and the G.O.P. Vent Politely," New York Times (January 30).

Benditt, Theodore M. 1979. “Compromising Interests and Principles.” In Compromise in Ethics, Law and Politics, Nomos XXI, eds. J. Roland Pennock and John W. Chapman. New York University Press. 26-37.

Benjamin, Martin. 1990. Splitting the Difference: Compromise and Integrity in Ethics and Politics Lawrence Kansas: University Press of Kansas.

Besson, Samantha. 2005. The Morality of Conflict: Reasonable Disagreement and the Law. Oxford and Portland Oregon: Hart Publishing.

Birnbaum Jeffrey and Alan Murray. 1988. Showdown at Gucci Gulch. New York: Vintage.

Blumer, Jay G. and Michael Gurvetich. 2001. “'Americanization’ Reconsidered: U.K.-U.S. Campaign Communications Across Time," In Mediated Politics, eds. W. Lance Bennett and Robert M. Entman. Cambridge University Press, 380-403.

Boehner, John 2009. “Taxpayer-Funded Abortion Is Not Health-Care Reform,” National Review (July 23)

Brady, David and Morris Fiorina, "Congress in the Era of the Permanent Campaign," In The Permanent Campaign and Its Future, eds. Thomas Mann and Norman Ornstein. Washington DC: American Enterprise Institute, 134-61.

Bohman, James,. 1996. Public Deliberation: Pluralism, Complexity, and Democracy. Cambridge MA: MIT Press.

Bradley, Bill. 2009. “Tax Reform's Lesson for Health Care Reform.” New York Times (August 30). 
Brownstein, Ronald. 2007. The Second Civil War: How Extreme Partisanship Has Paralyzed Washington and Polarized America. Penguin Press.

Bush, George H. W. 1988. "Address Accepting the Presidential Nomination at the Republican National Convention in New Orleans," August 18, 1988 The American Presidency Project, available at: http://www.presidency.ucsb.edu/ws/index.php?pid=25955

Carens, Joseph H. 1979. “Compromise in Politics.” In Compromise in Ethics, Law and Politics, Nomos XXI, eds. J. Roland Pennock and John W. Chapman. New York University Press, 230-56.

Cohn, Jonathan. 2010. “How They Did It: The Inside Account of Health Care Reform's Triumph." The New Republic (June 10): 14-25.

Conlan, Timothy J., Margaret T. Wrightson and David R. Beam. 1989. Taxing Choices: The Politics of Tax Reform. Washington: Congressional Quarterly Press.

Chong, Dennis and James N. Druckman. 2007. "Framing theory," Annual Review of Political Science 10: 103-26.

DeLay, Tom. 2006. Farewell Address, U.S. House of Representatives (June 8).

Demer, Lisa. 2009. "Murkowski: Don't tell lies about the health-care reform bill," Anchorage Daily News (August 11) http://www.adn.com/2009/08/11/895431/murkowskidont-tell-lies-about.html

Dobel, J. Patrick. 1990. Compromise and Political Action. Savage Maryland: Rowman and Littlefield.

Druckman, James N. 2010 (forthcoming). "What's It All About?: Framing in Political Science." In Perspectives on Framing, ed. Gideon Keren. New York: Psychology Press / Taylor \& Francis.

Dworkin, Ronald. 1986. Law's Empire. Cambridge MA: Harvard University Press.

FactCheck.org. 2007. “Clinton vs. Obama: Who's right on health care, Social Security?” November 16, http://www.factcheck.org/clinton_vs_obama.html

Fiorina, Morris P., with Samuel J. Abrams. 2009. Disconnect: The Breakdown of Representation in American Politics. Norman OK: University of Oklahoma Press.

Fiorina, Morris P., with Samuel J. Abrams and Jeremy C. Pope. 2010. Culture War? The Myth of a Polarized America, $3^{\text {rd }}$ edition. Longman.

Fiorina, Morris P. and Samuel J. Abrams. 2008. "Political Polarization in the American Public," Annual Review of Political Science. 11: 563-588. 
Galston, William A. 2010. “Can a Polarized American Party System Be 'Healthy'?” Issues in Governance Studies (April) 34: 1-20.

Gutmann, Amy, and Dennis Thompson. 2004. Why Deliberative Democracy? Princeton University Press.

Gutmann, Amy, and Dennis Thompson. 1996. Democracy and Disagreement. Harvard University Press.

Hacker, Jacob S. 2010. "The Road to Somewhere: Why Health Reform Happened," Perspectives 8: (forthcoming).

Heclo, Hugh. 2000. “Campaigning and Governing: A Conspectus.” In The Permanent Campaign and Its Future, eds. Thomas Mann and Norman Ornstein. Washington DC: American Enterprise Institute,1-37.

Ignatieff, Michael. 2007. “Getting Iraq Wrong.” New York Times Magazine (August 5).

Jones, Charles 0. 1998. Passages to the Presidency: From Campaigning to Governing. Washington: Brookings.

Kuflik, Arthur. 1979. "Morality and Compromise" In Compromise in Ethics, Law and Politics, Nomos XXI, eds. J. Roland Pennock and John W. Chapman. New York University Press, 38-65.

Kuttner, Robert. 2000. "Why Liberals Need Radicals." American Prospect (May 22)

Lizza, Ryan. 2009. “The Gatekeeper” New Yorker 85 (March 2).

Ornstein, Norman J. and Thomas E. Mann, eds. 2000. The Permanent Campaign and Its Future. Washington DC: American Enterprise Institute.

Mansbridge, Jane et al. 2010. "The Place of Self-Interest and the Role of Power in Deliberative Democracy." Journal of Political Philosophy, 18 (1): 64-100.

Margalit, Avishai. 2009. On Compromise and Rotten Compromises. Princeton University Press.

May, Simon Căbulea. 2005. "Principled Compromise and the Abortion Controversy." Philosophy \& Public Affairs. 33 (4): 317-348.

McCarty, Nolan, Keith Poole and Howard Rosenthal. 2008. Polarized America: The Dance of Ideology and Unequal. Cambridge MA: MIT Press.

Mill, John Stuart. 1977. On Liberty. In Collected Works, Essays on Politics and Society, vol. XVIII, ed. J. M. Robson, 213-310.

Mouffe, Chantelle. 2009. The Democratic Paradox. London: Verso. 
Muirhead, Russell. 2006. “A Defense of Party Spirit," Perspectives on Politics, 4:713-727.

Muirhead, Russell. 2009. "Respectable Partisanship." In The Arts of Rule, eds. S. Krause and M. A. McGrail. Lanham MD: Rowman \& Littlefield, 377-94.

Murray, Shailagh. 2010. "Republicans urge Democrats to start all over on health care." Washington Post (January 31).

Nyhan, Brendan. 2010. “Why the 'Death Panel' Myth Wouldn't Die: Misinformation in the Health Care Reform Debate". The Forum 8:1. http://www.bepress.com/forum/vol8/iss1/art5/?sending=11004 [accessed May 5, 2010]

Organizing for America.2008-2002.“Obama's Speeches.” http://origin.barackobama.com/ speeches/

"Parties, Partisanship, and Democratic Politics" 2009. Perspectives on Politics 7 (3): 621-29.

Richardson, Henry. 2002. Democratic Autonomy: Public Reasoning about the Ends of Policy. Oxford: Oxford University Press.

Rosenblum, Nancy. 2008. On the Side of Angels: An Appreciation of Parties and Partisanship. Princeton University Press.

Seelye Katherine Q. 2009.“Ads Question Opponents' Motives,” New York Times (August 18).

Smith, Ben. 2009. "Health reform foes plan Obama's 'Waterloo'” Politico (July 17) http://www.politico.com/blogs/bensmith/0709/Health_reform_foes_plan_Obamas_ Waterloo.html

Staff of The Washington Post. Landmark: The Inside Story of America's New Health-Care Law and What is Means for Us All, The Washington Post 2010.

Strahan, Randall. 1989. 'Members' Goals and Coalition-Building Strategies in the US House: The Case of Tax Reform," Journal of Politics 51 (2): 373-384

Thompson, Leigh, Jiunwen Wang and Brian C Gunia. 2010. "Negotiation," Annual Review of Psychology 61:491-515.

Thompson, Dennis F. 2007. "Mill in Parliament: When Should a Philosopher Compromise?" In J. S. Mill's Political Thought, eds. N. Urbinati and A. Zakaras. Cambridge University Press, 166-99.

Tilly, Charles and Sidney Tarrow. 2006. Contentious Politics. Boulder CO: Paradigm.

Witte, John F. 1991. "The Tax Reform Act of 1986: A New Era in Tax Politics?" American Politics Research 19 (4): 438-57. 
-44 - 